\title{
The Role of Customer Relationship Marketing in Improving SMEs Export Performance in Bali Province
}

\author{
I Putu Gde Sukaatmadja ${ }^{1}$, Henny Rahyuda ${ }^{2}$, Anak Agung Kartika Dewi ${ }^{3}$ \\ ${ }^{1,2,3}$ Program Study of Management Faculty of Economics and Business Udayana University
}

\begin{abstract}
This research was conducted constituted by the phenomenon of declining in export performance of SME industry in Bali and rapid development of information technology which could help SMEs to expand their market abroad (global market). Therefore, it is necessary to build a strategy for SMEs to target global market based on information technology which is Customer Relationship Marketing (CRM) in retaining customers to become loyal customers. The purpose of this study is to explain the role of CRM strategy based on IT Resources and Market Orientation in order to improve the export performance of SMEs in Bali. This study took place in all districts/ municipalities in Bali with a target population includes industrial stakeholders of SMEs that perform export activities. Based on Slovin's formula, the number of samples taken was as many as 105 persons. Data analysis was using SEM analysis.The results showed that IT Resource positively and significantly affects export performance, as well as market orientation affects export performance positively and significantly. Furthermore, IT Resource positively and significantly impacts CRM strategy, as well as market orientation influences export performance positively and significantly, and CRM positively and significantly impacts export performance.The study implication contributes to exporters to strengthen their IT resource and improve their market orientation and build better CRM so that export performance continues to increase.
\end{abstract}

Keywords: IT Resource, market orientation, CRM strategy, export performance

\section{Introduction}

In order to improve the economy of Indonesia in general and Bali in particular, the role of small and medium enterprises is necessary as one of the economic development pillars in Bali is empowerment of Small and Medium Enterprises (SMEs), in addition to tourism and agriculture. It was also revealed in the research result conducted by Yasa et al. (2013) which showed that improved performance of SMEs was able to significantly reduce poverty in Bali. In addition, Tambunan (2011) also found that SMEs is an industry that carries out economic activity amounted to $99.9 \%$ and employs $96.2 \%$ workers in Indonesia. Proof of SMEs role in boosting a country economy in order to overcome poverty was also shown in a study conducted by Dollar and Kraay (2002); Odd-Helge et al. (2006); Saravanan et al. (2008), Marlow (2009), and Akinboade \& Kinfack (2012).

This phenomenon shows how strategic SMEs role is in improving the economy of a region, including in Bali province. Unfavorable condition occurred in the last period, in which the performance of SMEs in Bali showed a decline. It also occurred to SMEs that serve global market. Data showed that export rate of Bali's product in December was $\$ 42,474,188$. This figure is lower than the export value in December 2012, decreasing as much as $4.87 \%$. (BPS Bali, 2014). This can occur for many reasons, among others, due to changes in external environment, such as higher competition intensity and low entry barriers into SME industry. In addition, SMEs internal factors such as Information Technology (IT) resource and market oriented culture is not maximized. Both internal factors largely determine export performance. Through IT resources, SMEs are able to develop customer database very well, having more intensive communication with consumers that leads to increased satisfaction and surely performance improvement that can be seen from the increase in sales volume, market share, and market reach. Likewise, market oriented culture encourages SME to always follow various changes in market preference and try to satisfy that preference to satisfy the consumer As these various issues present, therefore SMEs in Bali must consider to plan a strategy to maximize their export performance. Being based on IT resources and market oriented culture, SMEs Bali can develop CRM strategy.

SME strategy that is based on information technology is indeed suitable to be developed considering all businesses want to expand their market to global market by leveraging IT development. Since SMEs in Bali consists of several sectors, namely craft sector, services sector, food and beverages sector, it is necessary to create variations for each sector in order to provide optimal result. Such phenomenon urges SMEs to have a strategy to target global market (in this case IT based) so that performance can be improved, and the subsequent impact will certainly be able to reduce the levels of poverty (Santos, 2011; Ladzani \& Seeletse, 2012). 


\begin{abstract}
II. Research Hypotheses
The Influence of IT Resource on Export Performance

Hamilton and Assundi (2008) mentioned that investing in information technology is very important for SMEs, as information technology caused business dynamics to move fast, effectively, and efficiently, and the quality of services that accompany the sale of a product. Khong et al. (2010) found that by the use of information technology, companies can maintain and even improve service to customers so that customers remain satisfied. Yu et al. (2006) found that by transfer of technology, it is guaranteed that company will achieve profitability in the long term.

Based on previous empirical studies, the following hypothesis is proposed.
\end{abstract}

\title{
H1: IT Resource has positive and significant impact on export performance The Influence of IT Resource on CRM Strategy
}

IT resource is among the factors that determine the success of CRM implementation. IT resources that include personal resource, hardware and software resource, as well as other IT facilities will provide support toward CRM strategy operational. The greater the IT resources owned by a company the better its CRM strategy.

Based on previous empirical studies, the following hypothesis is proposed.

\section{H2: IT resource has positive and significant impact on CRM strategy The Influence of Market Orientation on Export Performance}

Market orientation is literally regarded as the extent to which a company involved in the response, and generation to market intelligence that applies to customers needs at present and in the future, strategies and steps taken by competitors, and broad business environment. Market-oriented companies adapt and implement marketing concept (Kohli \& Jaworski, 1990; Morgan et al., 2009). There are several previous studies that support this hypothesis, which is Afsharghasemi et al. (2013) stated that based on direct model there is significant and positive relationship between market orientation and export performance. Armario et al. (2008) stated the relationship between overall market orientation and export performance is positive and significant. In addition, the research shows that market orientation is a supporting factor in internationalization process of SMEs.

Based on previous empirical studies, the following hypothesis is proposes.

\section{H3: Market orientation has positive and significant impact on export performance The Influence of Market Orientation on CRM Strategy}

Several literatures showed that market orientation has positive relationship with mutual good relationship between company and buyers in international context, as shown in research result conducted by Blesa \& Bigne (2005). In addition, new perspective has been proposed by Foley \& Fahy $(2004 ; 2009)$ which focuses on market orientation as a source of market-based knowledge as it enables organization to develop capillary capacity to perform at a higher level than its competitors. According to Kohli and Jaworski (1990) who developed market orientation intelligence perspective, orientation with a mixture of three activities, namely the organization of market intelligence pertaining to current and future customer needs, dissemination of intelligence within the organization and also responsive to competitive intelligence.

Previous research that supports this hypothesis is Afsharghasemi et al. (2013) showed that there is significant relationship between market orientation and CRM in manufacturer SMEs in Malaysia. Based on previous empirical studies, the following hypothesis is proposed.

\section{H4: Market orientation has positive and significant impact on CRM strategy The Influence of CRM Strategy on Export Performance}

A company that develops CRM strategy is generally able to increase customer satisfaction resulting in increased sales which improves the company performance. This is consistent with the research results conducted by Chelliah et al. (2010), which showed that CRM program built in the company is able to increase the access to international market and affecting export performance. In addition there are other researchers such as Chetty \& Campbell (2003) found similar result that CRM strategy has significant positive effect on export performance. Likewise, research results of Chang and Ku (2009), showed that CRM implementation can improve organizational performance. It also supported by several researchers (Yim et al., 2005; Akroush, 2011; Moreno \& Melendez, 2011).

Based on previous empirical studies, the following hypothesis is proposed. 
The Role of Customer Relationship Marketing in Improving SMEs Export Performance in Bali ..

\section{H5: CRM strategy has positive and significant impact on export performance III. Research Method}

The research conducted in SMEs in all districts/municipalities in Bali Province, which are Denpasar, Gianyar, Bangli, Klungkung, Karangasem, Buleleng, Jembrana, Badung, and Tabanan regency.

The subject in this study is Small and Medium Enterprises (SMEs) in Bali province. Object in this study is the export performance of SMEs which is affected by IT resource, market orientation and CRM strategy.

In this study, there are three types of variables to be analyzed, these variables are:

1) ExogenousVariable

IndependentVariable: IT Resource (X1)

Market Orientation (X2)

2) Intervening Variable

MediatingVariable: CRM Strategy $\left(\mathrm{Y}_{1}\right)$

3) Endogenous Variable

Dependent Variable: SMEs Export Performance $\left(\mathrm{Y}_{2}\right)$

Each variable or research indicators are classified as follows:

Table 1: Research Constructs and Indicators

\begin{tabular}{|c|c|c|c|}
\hline $\begin{array}{c}\text { Construct } \\
\text { Classification }\end{array}$ & Construct & Indicator & Source \\
\hline \multirow[t]{2}{*}{ Exogenous } & IT Resource (X1) & $\begin{array}{l}\text { 1. Have web. } \\
\text { 2. Have IT facility } \\
\text { 3. Have IT resource } \\
\text { 4. Have IT budget } \\
\end{array}$ & Adeosun et al. (2009) \\
\hline & Market Orientation (X2) & $\begin{array}{l}\text { 1. Consumer orientation } \\
\text { 2. Competitor orientation } \\
\text { 3. Cross functional coordination }\end{array}$ & Afsharghasemi et al. (2013) \\
\hline Intervening & CRM Strategy $\left(\mathrm{Y}_{1}\right)$ & $\begin{array}{l}\text { 1. Good relationship with customer } \\
\text { 2. Have commitment to customers. } \\
\text { 3. Maintain intensive } \\
\text { communication with customer. } \\
\text { 4. Handle customer conflict }\end{array}$ & $\begin{array}{l}\text { Palmetier et al., } 2006 \text {; } \\
\text { Velnampy \& Sivesan (2012) }\end{array}$ \\
\hline Endogenous & $\begin{array}{l}\text { SME Export Performance } \\
\left(\mathrm{Y}_{2}\right)\end{array}$ & $\begin{array}{l}\text { 1. Export market } \\
\text { 2. Export volume } \\
\text { 3. Export profit }\end{array}$ & $\begin{array}{l}\text { Zhou et al., 2007; } \\
\text { Afsharghasemi et al. (2013) }\end{array}$ \\
\hline
\end{tabular}

The research population is all SMEs in Bali province which perform export activities. The sample size was 105 SMEs in Bali. Determination of sample size in this study was using Slovin's formula. This way it is expected that the entire sample is representative in reflecting SMEs in each district/municipalities and eventually able to represent the whole territory of Bali province.

Indicators of IT resource variable, market orientation, CRM strategy and export performance is measured by the perception of the owners or managers of SMEs as strategists using five levels of Likert scale, from strongly disagree $=1$, disagree $=2$, quite agree $=3$, agree $=4$, and strongly agree $=5$. Measurement of the variables conducted during the beginning of July 2016 until the end of July 2016.

This study uses two types of data: 1) Primary data, obtained from the completed questionnaires by respondents in this case are owners or managers of SMEs in Bali province; 2) Secondary data, obtained from other sources that support research. Secondary data was obtained from Bali Central Bureau of Statistics and the Indonesian Entrepreneurs Association (Apindo) which already perform export activities.

Data was collected in two ways, through questionnaires and interview with the owners or managers of SMEs, SMEs observer/academia. The instruments were tested for validity and reliability in order to measure what wanted to be measured and confirm the consistency of responses given by respondents. Testing instruments validity using correlation technique of Pearson Product Moment with minimum $r$ limit $=0,3$ (Sugiyono, 2014: 150). Testing instrument reliability was performed by calculating reliability coefficient of Cronbach's Alpha with minimum limit of Alpha coefficients> 0.6 (Sekaran, 2003: 312). Both tests were using SPSS computer program. This analysis is used to describe the research variables, without generalization. The collected data then tabulated in tables and explained descriptively. Descriptive measure is the provision of figures, both in the number of respondents and average value of respondent answers and the percentage. Causal relationships defined in this study using a model that is not simple, the variables in the model form recursive relationship. This form of causal relationship requires an analytical tool that is able to explain the relationship, thus inferential statistical method used in this research analysis is Structural Equation Modeling (SEM). 


\section{Results And Discussion}

Respondents in this study described in general by presenting their characteristics, derived from gender and education level. The number of respondents in this study is as many as 105 people. Based on Table 2 respondent classification by sex shows that male respondents are 61.9 percent and female respondents are 38.10 percent. The next classification is based on education, it showed that the majority of respondents are high school graduate with a percentage of 57.14 percent, respondents with bachelor degree are 19.05 percent, Diploma 4 graduate with a percentage of 2.86 percent, Diploma 3 graduate with a percentage of 7, 62 percent, Diploma 2 graduate with a percentage of 9.52 percent and finally Diploma 1 graduate with a percentage of 3.81 percent.

Table 2 Respondent Characteristic

\begin{tabular}{|c|c|c|c|c|}
\hline No & Characteristic & Classification & Respondent & Respondent Percentage \\
\hline \multirow[t]{2}{*}{1} & \multirow[t]{2}{*}{ Gender } & Male & 65 & 61.90 \\
\hline & & Female & 40 & 38.10 \\
\hline \multicolumn{3}{|c|}{ Total } & 105 & $100 \%$ \\
\hline \multirow[t]{6}{*}{2} & \multirow[t]{6}{*}{ Education } & High School & 60 & 57,14 \\
\hline & & Bachelor Degree & 20 & 19.05 \\
\hline & & Diploma 1 & 4 & 3,81 \\
\hline & & Diploma 2 & 10 & 9,52 \\
\hline & & Diploma 3 & 8 & 7,62 \\
\hline & & Diploma 4 & 3 & 2,86 \\
\hline \multicolumn{3}{|c|}{ Total } & 105 & $100 \%$ \\
\hline
\end{tabular}

Source: Primary Data Tabulation

\section{SEM Analysis Results}

Theoretical model on conceptual framework of a study is said to be fit if supported by empirical data. The results of SEM analysis (Appendix 6) showed the testing result of overall goodness of fit models to determine whether the hypothetical model is supported by empirical data as shown in Figure 1.

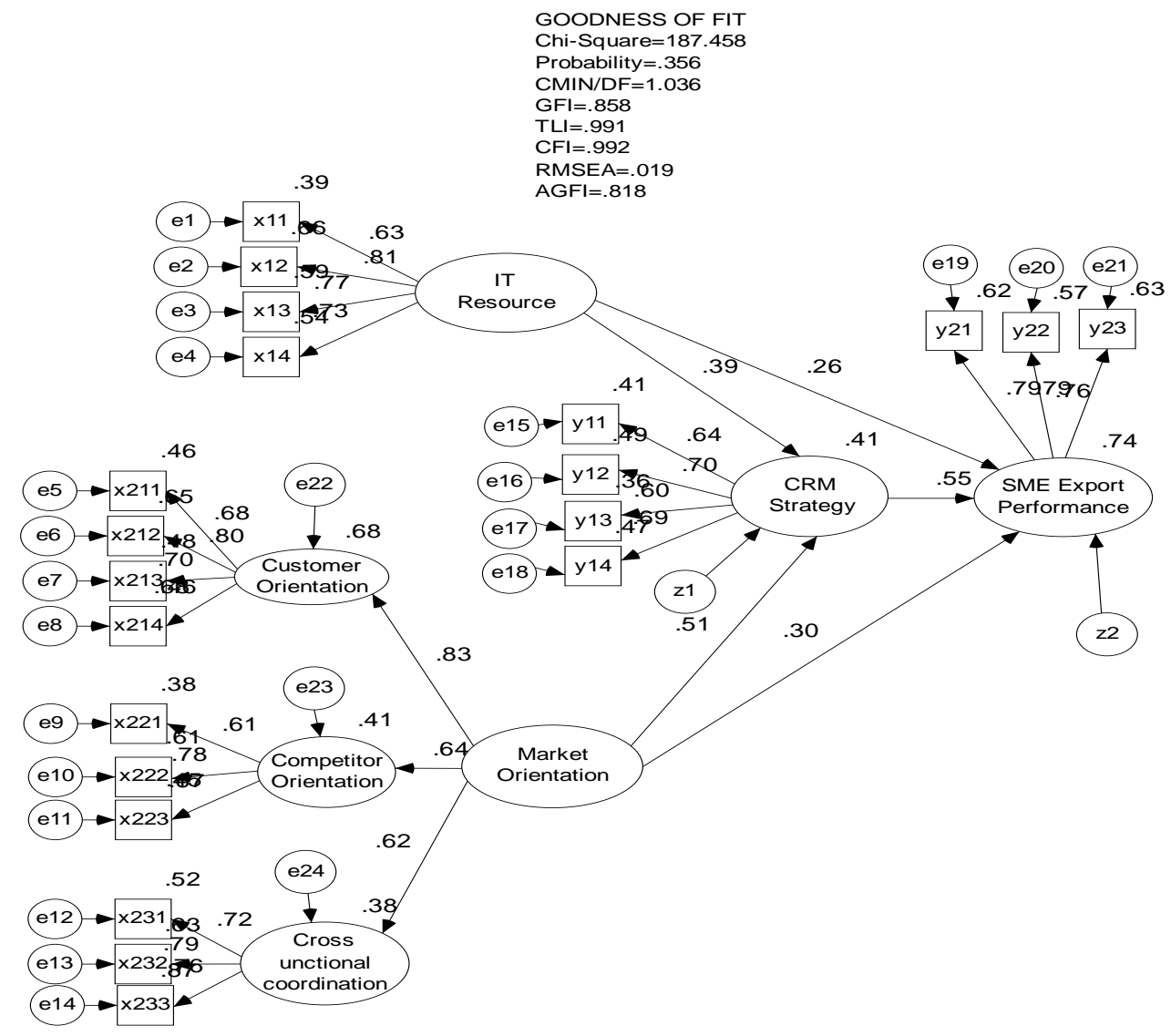

Figure 1. SEM Model

Hypothesis testing is done by $\mathrm{t}$ test on each direct path partially. Detailed analysis results contained in SEM analysis result. Table 3 presents the testing results of direct influence hypotheses. 


\section{Hypothesis 1: IT Resource (X) directly influences Export Performance (Y2)}

The SEM analysis results of variable IT Resources (X1) influence on SME Export Performance (Y2) showed direct influence path coefficients of 0.256 and p-value 0.020 . Since p-value $<5 \%$, therefore hypothesis "IT Resource (X1) directly influences SME Export Performance (Y2) is accepted. Given the positive path coefficient (0.256), means the relationship between the two variables is positive, the greater the IT Resource (X1), the higher the SME Export Performance (Y2). Conversely, the lower the IT Resource (X1), the lower the SME Export Performance (Y2).

Table 3: Testing Results of Direct Influence Hypotheses

\begin{tabular}{|l|l|l|l|c|}
\hline Dependent Variable & Independent Variable & Path Coefficient & $\boldsymbol{p}$-value & Annotation \\
\hline IT Resource (X1) & Export Performance (Y2) & 0,256 & 0,020 & significant \\
\hline Market Orientation (X2) & Export Performance (Y2) & 0,296 & 0,041 & significant \\
\hline IT Resource (X1) & CRM Strategy (Y1) & 0,392 & 0,003 & significant \\
\hline Market Orientation (X2) & CRM Strategy (Y1) & 0,509 & 0,001 & significant \\
\hline CRM Strategy (Y1) & Export Performance (Y2) & 0,554 & 0,000 & significant \\
\hline
\end{tabular}

Source: Appendix

\section{Hypothesis 1: IT Resource (X) directly influences Export Performance (Y2)}

The SEM analysis results of variable IT Resources (X1) influence on SME Export Performance (Y2) showed direct influence path coefficients of 0.256 and p-value 0.020 . Since $\mathrm{p}$-value $<5 \%$, therefore hypothesis "IT Resource (X1) directly influences SME Export Performance (Y2) is accepted. Given the positive path coefficient (0.256), means the relationship between the two variables is positive, the greater the IT Resource (X1), the higher the SME Export Performance (Y2). Conversely, the lower the IT Resource (X1), the lower the SME Export Performance (Y2).

\section{Hypothesis 2: Market Orientation (X2) directly influences Export Performance (Y2)}

From the result of SEM analysis, the influence of Market Orientation (X2) on Export Performance (Y2) has direct influence path coefficient of 0.296 and p-value 0.041 . Since p-value $<5 \%$, therefore hypothesis "Market Orientation (X2) directly influences Export Performance (Y2)" is accepted. Given the positive path coefficient (0.296.), it means the relationship between the two variables is positive, where the higher the Market Orientation (X2), the higher the Export Performance of SMEs in Bali (Y2).

\section{Hypothesis 3: IT Resource (X1) directly influencse CRM Strategy (Y1)}

The results of SEM analysis on the influence of IT Resource (X1) on SME's CRM Strategy (Y1) showed direct influence path coefficient of 0.392 and p-value 0,003 . Since p-value $<5 \%$, therefore hypothesis "IT Resource (X1) has direct influence on SME's CRM Strategy (Y1) is accepted. Given the positive path coefficient (0.392), this means that relationship between the two variables is positive, where the higher the IT Resource (X1), the higher the SME's CRM Strategy (Y1). Conversely, the lower the IT Resource (X1), the lower the SME's CRM Strategy (Y1).

\section{Hypothesis 4: Market Orientation (X2) directly influences CRM Strategy (Y1)}

From the result of SEM analysis, the influence of Market Orientation (X2) on CRM Strategy (Y1) has direct influence path coefficient of 0.509 and p-value 0.001 . Since p-value $<5 \%$, therefore hypothesis "Market Orientation (X2) directly influences CRM Strategy (Y1)" is accepted. Given the positive path coefficient (0.509), this means that relationship between the two variables is positive, meaning that the higher the Market Orientation (X2), the higher the implementation of CRM Strategy (Y1).

\section{Hypothesis 5: CRM Strategy (Y1) directly influences Export Performance (Y2)}

From the result of SEM analysis, the influence of CRM Strategy (Y1) on SME Export Performance (Y2) has direct influence path coefficient of 0.554 and p-value 0.000 . Since p-value $<5 \%$, therefore hypothesis "CRM strategy (Y1) directly influences SME Export Performance (Y2)" is accepted. Given the positive path coefficient (0.554), this means that relationship between the two variables is positive, meaning that the higher the implementation of CRM Strategy (Y1), the higher the SME Export Performance (Y2), and vice versa.

\section{Discussion}

From the validity and reliability testing, it can be seen that each indicator has been able to measure the variable and concept it meant to measure, and between one and another concept is dependent in nature. By performing confirmatory factor analysis (goodness of fit test and weight factor significance test) it has been shown that the observed variable reflects factor that is analyzed. With overall model fit test (goodness of fit test and regression weight causality test) it has been shown that the overall model is fit and causality could be tested. 


\section{The Influence of IT Resource on Export Performance}

Hypothesis testing on the influence of IT Resources on Export Performance showed that IT Resources significantly and positively influences export performance of SMEs. It means that the greater the IT resource owned by SME in Bali, such as having website, IT facilities, IT department, and allocated budget for IT, the export performance of SMEs in Bali will be improved.

\section{The Influence of Market Orientation on Export Performance}

Hypothesis testing on the influence of market orientation on SME Export performance showed that Market Orientation has positive and significant impact on SME Export Performance. It means the better the companies understand their market through consumer orientation approach, competitors and inter-functional, the export performance of SMEs in Bali will be improved. The results support the finding of Ahimbiswe (2013), Salim \& Sulaiman (2011), Johnson et al. (2009), (Shefer and Frenkel, 2005) and Calantone et al. (2002), which mentioned that Market Orientation significantly and positively affects SME export performance.

\section{The Influence of IT Resource on CRM}

Table 3 showed that IT Resource has significant impact on CRM strategy. This result is evidenced by the p-value of 0.003 which is smaller than 0.05 . The relationship between IT Resource and CRM Strategy shows positive effect characterized by the inner weight of 0,392. This result can be interpreted that the higher the market orientation, the more intensive the implementation of CRM strategy by SMEs in Bali. The result is consistent with the real situation where stronger market orientation leads to more inrensive CRM Strategy. In this study, Market Orientation indicators which are formed by three dimensions namely customer orientation, competitor orientation, and cross-functional coordination has an important role to a more intensive implementation of CRM strategy.

\section{The Influence of Market Orientation on CRM}

Table 3 showed that market orientation has significant influence on CRM strategy. This result evidenced by p-value of 0,001 less than 0.05 . Relationship between Market Orientation and CRM Strategy shows positive influence characterized by the inner weight of 0,509. This result can be interpreted that the higher the market orientation, the more intensive the implementation of CRM strategy by SMEs in Bali. The result is consistent with real situation where stronger market orientation leads to more intensive CRM Strategy implementation. In this study, Market Orientation indicators which are formed by three dimensions namely customer orientation, competitor orientation, and cross-functional coordination has an important role to intensify the implementation of CRM strategy. The result is consistent with the result of Urban and Govender (2012) \& Afsharghasemi et al. (2013).

\section{The Influence of CRM on Export Performance}

Table 3 showed that CRM strategy has significant impact on SME Export Performance. This result evidenced by the p-value of 0.000 less than 0.05 . The relationship between CRM strategy and SME Export Performance shows positive influence characterized by the inner weight of 0.554 . These result means that more intensive the CRM strategy, the higher the export performance of SMEs. In this study, CRM Strategy indicators which are formed by fostering good relationship with customers, maintaining communication with customers, building customer trust, and handling customer issues have an important role on SME Export Performance in Bali. The result of this study is consistent with empirical research conducted by Mitrega and Katrichis (2010).

\section{Research implication}

Theoretical implication derived from this research is that IT resource, market orientation, and CRM positively and significantly influence export performance of SMEs. Then CRM is able to significantly mediate the influence of IT resource and market orientation on export performance where CRM is a partial mediating variable. This shows that IT resource, market orientation and CRM are all factors affecting export performance. Through this research, students are able to apply knowledge and theory that is obtained during the lectures, moreover this study is expected to provide information on the factors that affect export performance of SMEs in Bali, namely IT resource, market-oriented culture, and building CRM.

This study provides input to exporter SMEs to pay attention to their resources, especially IT resource and market oriented culture so that their export performance improved. In addition, SMEs in Bali need to build a CRM system in order to strengthen good relationship with customers thus export performance is also improved. 


\section{Research Limitation}

Various limitations are also found in this study, primarily due to the following things. 1) The scope of this research is only covering SMEs in Bali in general, so the result of this study can not be generalized to each sector of SME. 2) The study was conducted only at a certain time that is periodic in which the environment will continue to experience a dynamic change.

\section{Conclusion}

Based on the research result, discussion and interpretation that have been described in the previous chapter with reference to several theories and previous research results, then the following conclusions can be formulated.

1. IT Resource positively and significantly influences SME export performance, means the higher the IT resource owned by SME in Bali, SME export performance is improved.

2. Market Orientation has positive and significant impact on export performance of SME, meaning that the higher the Market Orientation of SME in Bali, the export performance is also higher.

3. IT Resource has positive and significant impact on CRM strategy, meaning that the higher the IT Resource of SME in Bali, CRM strategy is also improved.

4. Market Orientation has positive and significant impact on CRM strategy, meaning that the higher the Market Orientation of SME in Bali, CRM strategy is also improved.

5. CRM Strategy has positive and significant impact on SME export performance, meaning that the higher the CRM Strategy applied by SME, export performance is also improved.

\section{References}

[1]. Adeosun, O., Adeosun, T.H. \& Adetunde, I.A., 2009, Strategic Application of Information and Communication Technology for Effective Service Delivery in Banking Industry. Journal of Social Science, Vol. 5, No.1, 47-51.

[2]. Akinboade-akinloye, Oludele \& Kinfack, Emilie Chanceline, 2012, Regulation, Awareness, compliance and SME Performance in Cameroon's manufacturing and retail sectors, International Journal of Social Economics, Vol. 39, Iss: 12, pp. 1 - 30.

[3]. Anshari, Y., Pervan, S. \& Xu, J., 2013, Innovation and Business Performance of SMes: The Case of Dubai. Education, Business and Society: Contemporary Middle Eastern Issues, Vol.6, No.34.

[4]. Afsharghasemi, A., Zain, M., Sambasivan, M., \& Imm, S.N.S. 2013. Market Orientation, Government Regulations, Competitive Advantage and Internationalization of SMEs: A Study in Malaysia. Journal of Business Administration Research, Vol. 2, No. 2, pp.13-22.

[5]. Akroush, M.N., Dahiyat, S.E., Gharaibeh, H.S. \& Abu-Lail, B.N. 2011. Customer relationship management implementation: an investigation of a scale's generalizability and its relationship with business performance in a developing country context, International Journal of Commerce and Management, Vol. 21, No. 2, pp. 158-191.

[6]. Armario, JM., Ruiz, D.M., \& Armario, E.M. 2008. Internationalization market orientation and Small and Medium-Sized Enterprises. Magazine of Small Business Management, Vol. 46, pp. 485-511.

[7]. Badan Pusat Statistik Bali, 2014, Data Ekspor.

[8]. Buhalis, D. 2003. eTourism. Information technology for strategic tourism management. Essex: Pearson Education Limited

[9]. Bernardin, H. J. \& Russel, E.A., 1993. Human Resource Management, An Experential Approach. Mc. Graw Hill International Edition, Singapore. Mac Graw Hill Book Co.

[10]. Bigne, E. \& A. Blesa, 2003. Market Orientation, Trust and Satisfaction in Dyadic Relationships: A Manufacturer-Retailer Analysis, International Journal of Retail \& Distribution Management, Vol. 31, No. 11, pp. 574-590.

[11]. Blesa, A. \& E. Bigne. 2005. The Effect of Market Orientation on Dependence and Satisfactionin Dyadic Relationships, Marketing Intelligence \& Planning, Vol. 23, No. 3, pp. 249-265.

[12]. Berry, Leonard L. 1995. Relationship marketing of services-growing interest, emerging perspectives, Journal of the Academy of Marketing Science, Vol. 23, No. 4, pp. 236-245.

[13]. Covin \& Slevin, 1989. Strategic Management of Small Firms in Hostile and Benign Environments. Strategic Management Journal Vol. 10, pp. 75-87.

[14]. Chang, H. \& Ku, P. 2009, Implementation of relationship quality for CRM performance: acquisition of BPR and organizational learning, Total Quality Management, Vol. 20 No. 3, pp. 327-348.

[15]. Chan, J. O. 2006. The Anatomy of Real Time CRM. Communication of the IIMA, Vol. 1, Issue 6, pp. $115-124$.

[16]. Chelliah, S., Pandian, S., Solomon, M., \& Munusamy, J. 2010. Moderate effect size of the company: The internationalization of small and medium enterprises (SMEs) in the manufacturing sector. African Journal of Business Management, Vol. 4, pp. 30963109.

[17]. Chetty, S., \& Campbell-Hunt, C. 2003. Road to the internationalization of small to medium-sized companies: the global fight against regional approach. European Magazine of Marketing, Vol. 37, pp. 796-820.

[18]. Chong, H., White, R.E. \& Prybutok. V. 2001. Relationship among organizational support, JIT implementation, and performance, Industrial Management \& Data Systems, Vol. 101, No. 6, pp. $273-281$.

[19]. Dollar David \& Kraay Aart, 2002, Growth is good for the poor. Journal of Economic Growth, Springer, Vol. 7 No. 3, pp.195-225

[20]. Ferdinand, Augusty. 2002. Structural Equation Modeling dalam Penelitian Manajemen: Aplikasi Model - Model Rumit Untuk Tesis Magister dan Disertasi Doktor. Semarang: Fakultas Ekonomi Undip.

[21]. Foley A. \& Fahy, J. 2004. Towards a Further Understanding of the Development of Market Orientation in the Firm: a Conceptual Framework Based on the Market-sensing Capability, Journal Strategic Marketing, Vol. 12, No. 4, pp. 219-230.

[22]. Foley A. \& Fahy, J. 2009. Seeing Market Orientation Through a Capabilities Lens. European, Journal Marketing, Vol. 43, No.1/2, pp. 13-20.

[23]. Gupta, A.K. \& J. MacDaniel, 2002. Creating Competitive Advantage by Effectively Managing Knowledge: A Framework for Knowledge Management. Journal of Knowledge Management Practice, Vol.3, No.2, pp.40-49.

[24]. Guzmán, Gonzalo M., Serna, María del C.Martínez, Torres, Gabriela, C. López \& Ramirez, Ricardo García, 2012, Competitiveness in Manufacturing SMEs: A Perspective of México. International Journal of Arts and Commerce, Vol. 1 No. 4. 
[25]. Hamilton, Leonora C. \& Asundi, R. 2008, Technology Usage and Innovation Its Effect on the Profitability of SMEs, Management Research News, Vol. 31, No. 11, pp. 830-845

[26]. Hair, J.F., Black, W.C., Babin, B.J., Anderson, R.E. \& Tatham, R.L. 2010. Multivariate Data Analysis a Global Perspective, 7th ed., Pearson Education, Upper Saddle River, NJ.

[27]. Hengst, M. \& Sol, H.G. 2001. The Impact of Information and Communication Technology on Interorganizational Coordination: Guidelines from Theory. Informing Science, Special Series on Information Exchange in Electronic Markets, Vol. 4, No. 3.

[28]. Jansen, J.J., Frans A.J. \& Henk W.V. 2006. Exploratory Innovation, Exploitative Innovation, and Performance: Effects of Organizational Antecedents and Environmental Moderators. Management Science, Vol. 52, No. 11, pp. 1661-1674.

[29]. Jauch L.R. \& Glueck, W.F., 1998. Manajemen Strategis dan Kebijakan Perusahaan. Edisi Ketiga, dialih bahasa Murad dan Sitanggang. Penerbit Erlangga, Jakarta

[30]. Kohli, A.K., \& Jaworski, B.J. 1990. Market orientation: the construct, research propositions, and managerial implications. The Journal of Marketing, pp. 1-18.

[31]. Khong, S.T., Sing, C.C., Binshan,L. \& Uchenna, C.E. 2010. Internet Based ICT: Adoption among SMEs, Demographic Versus Benefits, Brries and Adoption Intention. Journal of Enterprise Information Management, Vol. 23, No. 1, pp. 21-55.

[32]. Lee D. Y. \& Tsang E. W. K. 2001, The effect of Entrepreneurial Personality, Background and network Activities Growth. Journal of Management Studies, Vol. 38, No. 4, pp. 583-602.

[33]. Lee, Y.K., Kim, Y.S., Son, M.H. \& Lee, D.J. 2011. Do emotions play a mediating role in the relationship between owner leadership styles and manager customer orientation, and performance in service environment?. International Journal of Hospitality Management, No. 30, pp. 942-952.

[34]. Lee, C.K., Song, H.J., Lee, H.M.. Lee, S. \& Bernhard, B.J.2013. The impact of CSR on casino employees organizational trust, job satisfaction, and customer orientation: An empirical examination of responsible gambling strategies. International Journal of Hospitality Management, No. 33, pp. 406-415.

[35]. Liu, H., Ke, Weiling., Wei, K.K. \& Hua Zhongsheng. 2013. Effects of Supply Chain Integration and Market Orientation on Firm Performance: Evidence from China.International Journal of Operations \& Production Management, Vol. 33, No. 3, pp. 322-346

[36]. Marlow, S 2009, Challenging the 'myth' of the under-performing female entrepreneur, Enterprising Matters", E-Magazine, Spring, available at http://www.isbe.org.uk

[37]. Moreno, G.A. \& Melendez, P.A. 2011. Analyzing the impact of knowledge management on CRM success: the mediating effects of organizational factors, International Journal of Information Management, Vol. 31, pp. 437-444.

[38]. Morgan, N.A., Vorhies, D.W. \& Mason, C.H. 2009. Market orientation, marketing capabilities, and firm performance. Strategic Management Journal, Vol. 30, pp. 909-920.

[39]. Narver, J.C. \& Slater, S.F. 1990. The influence of market orientation on business profitability. Journal of Marketing Research, Vol. 54, No. 20.

[40]. Odd-Helge Fjeldstad, Ivar Kolstad, Knut Nygaard, 2006, Bribes, taxes and regulations: Business constraints for micro enterprises in Tanzania, Working paper, 2006: 2.

[41]. Palmatier, R. W., Gopalakrishna, S. \& Houston, M. B. 2006. Returns on business-to-business relationship marketing investments: strategies for leveraging profits. Marketing Science, Vol. 25, No. 5, pp. 477-493

[42]. Pavic, S., Koh, S.C.L., Simpson, M., \& Padmore, J. 2007,Could e-Business Create a Competitive Advantage in UK SMEs? Benchmarking: An International Journal, Vol. 14, No. 3, pp. 320-351.

[43]. Porter, Michael E. 2008. Keunggulan bersaing, Menciptakan dan Mempertahankan Kinerja Unggul. Jakarta: Binarupa Aksara.

[44]. Safarnia, H., Akbari, Z., \& Abbasi, A. 2011. Review of market orientation and competitive advantage in the industrial estates companies (Kerman, Iran): Appraisal of model by AMOS graphics. World J. Soc. Science. Vol. 1, No. 5, pp. 132-150.

[45]. Saravanan Ajitha , Prashant Gupta \& Shambhu Ghatak, 2008, SME scenario around the world, available at http://eindia2007.blogspot.com/2008/07/sme-scenario-around-world.html.

[46]. Santos Maria, 2011, CSR in SMEs: strategies, practices, motivations and obstacles, Social Responsibility Journal, Vol. 7, Iss: 3 pp. $490-508$.

[47]. Sekaran, Uma. 2003. Research Methods For Business. New York: John Willey and Sons, Inc

[48]. Subiyanto. 2000. Metode Penelitian Administrasi. Bandung: CV. Alfabeta.

[49]. Sugiyono. 2014. Memahami Penelitian Bisnis (Pendekatan Kuantitatif, Kualitatif dan R\&D). Bandung: Alfabeta.

[50]. Solimun. 2002. Structural Equation Modelling (SEM): Lisrel dan Amos, Cetakan Pertama. Malang: Universitas Negeri Malang.

[51]. Taleghani, Mohammad., Gilaninia, Shahram. \& Talab, Sahar Matloub. 2013 Market Orientation and Business Performance. Singaporean Journal of Business Economics and Management, Vol. 1, No. 11.

[52]. Tambunan Tulus Tahi Hamonangan, 2011, Development of small and medium enterprises in a developing country The Indonesian case, Journal of Enterprising Communities: People and Places in the Global Economy, Vol. 5 No. 1, pp. 68-82.

[53]. Velnampy \& Sivesan. 2012. Impact of customer relationship marketing on customer value creation in mobile service providers - a Sri Lankan experience, Herald Journal of Marketing and Business Management, Vol. 1, No.1, pp. 016 - 021.

[54]. Verreynne, M. 2006. Strategy Making Process and Firm Performance in Small Firms. Journal Management and organization, Vol. 12, pp. 209-222.

[55]. Yasa Kerti, N.N., Jawas Abdullah, Sukaatmadja P.G., Sribudhi Kembar, \& Marhaeni A.A.N., 2013, SME performance improvement and its effect on the poverty reduction in Bali, International Jurnal of Business Management Invention, Vol. 2, Issue 4, pp.01-12.

[56]. Yu, C.S., 2006, Exploring Influences on Taiwanese e-Marketplace Adoption Decisions. Journal of Global Information Technology Management, Vol. 9, No. 2, pp. 5-21

[57]. Yim, F.H.K., Anderson, R.E. \& Swaminathan, S. 2005. Customer relationship management: its dimensions and effect on customer outcomes, Journal of Personal Selling and Sales Management, Vol. 24, No. 4, pp. 263-278.

[58]. Zhou, L.X., Wu, W.P., \& Luo, X.M. 2007. Internationalization and performance of SMEs globally born: The mediating role of social networks. Journal of International Business Studies, Vol. 38, pp. 673-690.

[59]. Zhou, K. Z., Brown, J. R., \& Dev, C. S. 2009. Market orientation, competitive advantage, and performance: A demand-based perspective. Journal of Business Research, Vol. 62, No. 11, pp. 1063-1070. 